\title{
Child Development: A Cultural Approach
}

\author{
Celeste Antão \\ Polytechnic Institute of Bragança, UICISA: E-Higher School of Health, Portugal
}

Submission: January 09, 2020; Published: January 22, 2020

*Corresponding author: Celeste Antão, Polytechnic Institute of Bragança, UICISA: E-Higher School of Health, Bragança, Portugal

\begin{abstract}
Child development is the subject of interest from different disciplinary areas and different professionals. In this article, we intend to reflect on development and learning related to culture, thinking of paremiological expressions as pedagogical resources in the surveillance of the child taking into account the development areas of Mary Sheridan. To this end, a research was carried out in the paremiology scope of passive generational messages to reflect child development. Behavior/social adaptation and emotions were the most found.
\end{abstract}

Keywords: Child development; Culture; Paremiology

\section{Introduction}

The child is a product of several factors: adaptive evolution of his species, the genes of the parents, the social physical environment and also the cultural environment in which he lives and interacts Pinto [1]. Development refers to a complex, continuous, dynamic and progressive transformation in relation to growth, maturation, learning and psychic and social aspects. It is mediated by other people, families, health professionals, and educators who delimit and attribute meanings to their reality Secretary of State for Health [2]. Culture encompasses multiple

knowledge, including popular wisdom, constituting through the relationship between man and nature. With the cultural repertoire, human beings use forms of communication, such as orality, to transmit it, which includes expressions as a means of acquiring knowledge necessary for survival and as an instrument of resistance to the globalized world. Vitor \& Santos [3] Chart 1 shows that in the area of behavior and social adaptation where more expressions were found. Related to fine motricity no expressionwasfound (Table 1).

Table 1: Distribution of paremiological expressions depending on development areas.

\begin{tabular}{|c|c|}
\hline $\begin{array}{c}\text { Posture and Motricity } \\
\text { Global }\end{array}$ & $\begin{array}{l}\text { "Crawling one learns to walk" } \\
\text { "The year andante, both, speaker" } \\
\text { "On the year walk, at both speak" }\end{array}$ \\
\hline \multicolumn{2}{|l|}{$\begin{array}{l}\text { Vision and } \\
\text { Fine Motricity }\end{array}$} \\
\hline Hearing and Language & "The year andante, both, speaker" \\
\hline $\begin{array}{c}\text { Vision / manipulation } \\
+ \\
\text { Emotions }\end{array}$ & $\begin{array}{l}\text { "The master said, Whoever moderates, is rarely lost." (Confucius) } \\
\text { "Worth another piece of bread with love, than chicken with pain" } \\
\text { "The child and the kitten go to those who make them pampering" } \\
\text { "Boys and birds, with all the affections" } \\
\text { "It's worth more mother's affection than breast milk" } \\
\text { "There is no need to be strong, it is to be flexible" }\end{array}$ \\
\hline Behavior Social adaptation & $\begin{array}{l}\text { "Education is consummated in example" } \\
\text { "Closed books don't make lyrics" } \\
\text { "It takes an entire village to educate a child" } \\
\text { "A gram of examples is worth more than a ton of advice" } \\
\text { "A child's life is like a piece of paper on which those who approach leave their mark" } \\
\text { "Learning is like the horizon, it has no limits" } \\
\text { "No matter how slow you go as long as you don't stop" (Confucius) }\end{array}$ \\
\hline
\end{tabular}




\section{Discussion}

The child's motor development is gradual. In a short time, they move from one acquisition to another. In order to have a good cognitive and motor development, it needs to be stimulated. The child's interactions with parents are fundamental to social and emotional development. Development also depends and is different from the place and culture where they live. Basic development such as crawling, speaking, walking, in any culture will occur in the same way, but it may not be in the same age group. It follows that their assessment must be carried out systematically, in order to be able to detect some deviations early. This evaluation is particularly important, and its application is recommended by the National Program for Child and Youth Health of the Ministry of Health [6].

The importance of understanding the relationship between culture, learning and education takes on greater importance if we think that we increasingly interact in a multicultural society. And it will be, this individual and at the same time collective relationship, that will foster a process of coexistence that will result in the improvement of interactions and learning.

The paremiological expressions found reveal that the child's acquisitions are progressive, occur from the simplest to the most complex and depend on a set of interactions. For learning to take place, for example, moderation, affections are extremely important. In terms of global motricity and language, as expected, he walks the year and speaks at the age of two [4]. Also underlying is the continuous process of competencies dependent on interaction with the environment [2]. These messages, when contextualized, can be an important tool in promoting the development / learning and training of parents in processes of interaction and promotion of safety [5]. Cultural influence still remains in the various manifestations and approaches in children, hence a harmonious relationship between scientific and cultural knowledge is possible.

Send feedback History Saved Community.

\section{Conclusion}

Due to their sound and rhythm, they can contribute to the approach of child development in a more motivating way. If it is true that "closed books do not make literate", also "in any situation we can have a proverb always at hand".

\section{References}

1. Pinto M (2009) Surveillance of psychomotor development and alarm signals. Rev Port Clin General 25: 677-687.

2. State Department of Health of Brazil (2005) Child tracking manual.

3. Souza JV R, Santos MB (2018) Use of popular sayings in the classroom.

4. Hockenberry M J, Winkelstein W (2011) Wong - Pediatric nursing fundamentals. Rio de janeiro.

5. Sheridan MD (1984) From birth to five years: children development progress. Hong Kong: The Nfer-Nelson Publishing Company.

6. General Directorate of Health (2013). National Program for Child and Youth Health. Lisbon: DGS.

7. Lopes RMF, Nascimento RfL, Sousa SG, Mallet LG, Argimon IIL (2010). Cognitive and motor development of children from zero to fifteen months: a review study.

\section{Your next submission with Juniper Publishers will reach you the below assets}

- Quality Editorial service

- Swift Peer Review

- Reprints availability

- E-prints Service

- Manuscript Podcast for convenient understanding

- Global attainment for your research

- Manuscript accessibility in different formats

( Pdf, E-pub, Full Text, Audio)

- Unceasing customer service

Track the below URL for one-step submission https://juniperpublishers.com/online-submission.php 